\title{
Unggul Bersaing Batik Jambi: Studi Batik Berkah Jambi
}

\author{
Titin Agustin Nengsih ${ }^{* 1}$, Ayu Minarsi ${ }^{2}$, Muhammad Ismail ${ }^{3}$ \\ ${ }^{1,3}$ Dosen Fakultas Ekonomi dan Bisnis Islam UIN Sulthan Thaha Saifuddin Jambi \\ ${ }^{2}$ Mahasiswa Fakultas Ekonomi dan Bisnis Islam UIN Sulthan Thaha Saifuddin Jambi \\ *Korespodensi : nengsih@uinjambi.ac.id
}

\begin{abstract}
The Jambi Batik Industry is currently experiencing a decline because a lot of the Jambi batik motifs circulating in the market are mostly supplied from the Java region. The effect of this condition is the original Jambi batik craftsmen get sluggishness in producing Batik. The purpose of this research is to determine the factors that influence Jambi batik to be competitive, especially Batik Berkah Jambi City. The predictors variables used are product innovation, product quality, and social media. The research method uses quantitative methods by obtaining primary data from a questionnaire by taking 100 respondents and secondary data from interviews with the gallery owner of Batik Berkah Jambi. The results show that the variables of product innovation, product quality, and social media have a significant effect on the competitive advantage of Jambi Batik. Furthermore, product innovation, product quality, and social media also have a significant effect on competitive advantage at Batik Berkah Jambi City with a coefficient of determination is $57.1 \%$ and the remaining $42.9 \%$ is influenced by other variables.
\end{abstract}

Keywords : Product Innovation, Product Quality, Social Media, Competitive Advantages

\section{Pendahuluan}

Kehadiran Usaha Mikro Kecil dan Menengah (UMKM) merupakan salah satu penyangga perekonomian Indonesia terutama perekonomian rakyat. Salah satu bentuk nyatanya adalah pada tahun 2017 UMKM memberikan kontribusi nyata pada Produk Domestik Bruto sebesar 60,34\%. UMKM memiliki peran penting bagi perekonomian Indonesia dengan beberapa keunggulan dengan memanfaatkan seluruh faktor produksi dan menciptakan nilai tambah di berbagai sektor. Namun persaingan dalam dunia UMKM merupakan sesuatu yang harus dihadapi baik pada industri dengan cakupan bisnis yang besar ataupun yang kecil. Persaingan di UMKM menjadi salah satu faktor ancaman bagi pelaku usaha baik di pesaing satu dengan lainnya yang sebenarnya memiliki kepentingan yang sama. Setiap pengusaha harus berusaha menampilkan yang terbaik untuk mendapatkan ketertarikan konsumen untuk membeli produk yang dihasilkannya. Oleh karena itu, strategi yang tepat guna memberikan nilai tambah pada produk yang dihasilkannya penting dikembangkan oleh setiap pengusaha agar bisa unggul bersaing dengan kompetitornya.

Salah satu faktor yang mempengaruhi keunggulan bersaing adalah inovasi produk. Inovasi merupakan ide, praktik, atau objek yang dianggap baru oleh individu atau pengguna (Gerald Hilss, 2008). Perusahaan melakukan inovasi produk dengan merancang berbagai desain produk dan memberikan nilai tambah pada suatu produk tersebut. Inovasi perlu ditingkatkan untuk meraih tingkat penjualan yang meningkat dan keterkaitan konsumen untuk membeli produk. Proses menciptakan cara baru dapat meningkatkan efisiensi dan efektivitas sehingga produk mempunyai keunggulan di pasar. Kualitas produk merupakan salah satu faktor dan perhatian utama bagi penyedia produk dan jasa karena kepuasan pelanggan merupakan hal yang paling utama agar tetap bersaing di pasaran. Kualitas adalah totalitas fitur dan karakteristik produk atau jasa yang bergantung pada kemampuannya untuk memuaskan kebutuhan yang dinyatakan atau tersirat (Philip \& kevin, 2009). Penjual sebaiknya menghantarkan kualitas menjadi lebih baik sehingga dapat memenuhi atau melebihi harapan pelanggan. Winda, dkk (2020) dalam penelitiannya menyatakan bahwa kualitas produk berpengaruh secara signifikan terhadap keunggulan bersaing. Saat ini Teknologi dan Informasi menjadi suatu kebutuhan dasar dalam kehidupan sehari-hari. Salah satu cara untuk memiliki keunggulan bersaing adalah penggunaan sarana teknologi informasi yang dapat dimanfaatkan bagi UMKM dalam peningkatan bisnis dengan cara bertukar informasi dalam jumlah besar secara efektif (Genelius \& Susan, 2011). Sosial media merupakan alat pemasaran yang dapat digunakan untuk memahami pelanggan dan calon pelanggan. Peran media sosial sangat penting dalam pemasaran produk karena dapat mempermudah jangkauan agar dikenal oleh masyarakat. Penggunaan media sosial juga merupakan sarana promosi paling murah namun memberi dampak yang signifikan bagi pelaku usaha.

Indonesia merupakan negara yang memiliki berbagai jenis industri kreatif atau industri kerajinan tangan (Nurman waddah,2019) seperti industri kerajinan batik. Keberadaan batik diidentikkan di pulau Jawa seperti Yogyakarta, Solo, atau Pekalongan, akan tetapi setiap provinsi juga banyak mengembangkan industri batik dengan ciri khas daerahnya. Salah satu provinsi yang banyak mengembangkan industri kreatif kerajinan batik adalah Provinsi Jambi yang terkenal di kalangan masyarakat Indonesia. Batik Jambi merupakan warisan budaya turun temurun sejak zaman kerajaan Melayu Jambi. Batik memiliki filosofi dan makna yang mendalam dan mempunyai ragam motif. Keberagaman ini membuat batik menjadi warisan budaya dan memiliki peran penting bagi kehidupan masyarakat Jambi. Salah satu galeri batik Jambi yang terkenal adalah galeri Batik Berkah. Batik Berkah adalah salah satu rumah 
batik yang selalu menghadirkan inovasi produk terbaru. Berdasarkan observasi awal, galeri ini memproduksi batik dengan berbagai aneka warna dan motif dan menawarkan beberapa hasil jadi dari kain batik meliputi kemeja, gaun, dasar batik, kemeja laki-laki, baju muslim, tas, dan berbagai aksesoris lainnya. Galeri ini memiliki beberapa cabang galeri seperti The Art of Batik Jambi Berkah (Jl. Soekarno-Hatta), Galeri Batik Jambi Berkah (Jl. MH Thamrin), The Art of Batik Jambi Berkah (daerah Simpang Pulai), dan Rumah Produksi Batik Jambi Berkah (Perumahan Benfica, Telanai Pura). Galeri ini menyediakan jenis batik tulis dan batik cap khas Jambi yang dibuat langsung dari pengrajin profesional. Pihak galeri ini juga menawarkan produk secara online seperti melalui media sosial yaitu Facebook dan Instagram serta pada website khusus galeri Batik Jambi Berkah.

Industri Batik Jambi saat ini kian menyusut dalam lima tahun terakhir (kompas, 2020). Salah satu alasannya adalah sebagian besar batik bermotif Jambi yang beredar di pasaran dipasok dari wilayah Jawa. Hal ini menyebabkan para pengrajin batik asli orang Jambi mengalami kelesuan. Dari kondisi ini menyebabkan harga batik Jambi produksi Jawa lebih digemari masyarakat karena harga lebih murah dibandingkan dengan batik Jambi produksi pengrajin Jambi sendiri.

Tabel 1

Data Penjualan Kain Batik Jambi di Batik Berkah

\begin{tabular}{lrrr}
\hline \multicolumn{1}{c}{ Bulan } & Tahun 2017 Kain/bidang & Tahun 2018 Kain/bidang & \multicolumn{1}{c}{ Tahun 2019 Kain/bidang } \\
\hline Januari & 502 & 660 & 775 \\
Februari & 525 & 570 & 625 \\
Maret & 575 & 575 & 690 \\
April & 452 & 455 & 625 \\
Mei & 560 & 600 & 675 \\
Juni & 425 & 475 & 550 \\
Juli & 475 & 490 & 599 \\
Agustus & 450 & 580 & 660 \\
September & 466 & 490 & 525 \\
Oktober & 525 & 627 & 775 \\
November & 475 & 560 & 751 \\
Desember & 550 & 650 & 770 \\
Total & 5980 & 6732 & 8020 \\
\hline Sumber & & & \\
\hline
\end{tabular}

Sumber : Data Batik Jambi Berkah

Berdasarkan data dari hasil penjualan rata-rata dari Batik Jambi Berkah tahun 2017 hingga tahun 2019 mengalami peningkatan (data ditunjukkan pada Tabel 1). Berdasarkan hasil wawancara ke pemilik galeri menyatakan bawa salah satu penyebab peningkatan ini adalah menghadirkan inovasi-inovasi produk terbaru serta memproduksi batik dengan berbagai aneka warna dan motif yang tengah digemari pasar. Berdasarkan observasi awal ini menyatakan bahwa perlu diteliti lebih lanjut tentang faktor-faktor yang harus diteliti agar penjualan batik Jambi terus hadir dan unggul bersaing dengan batik Jambi yang di produksi di Pulau Jawa. Berdasarkan latar belakang tersebut, penelitian ini mengangkat beberapa faktor yang mempengaruhi unggul bersaing batik Jambi khususnya Batik Jambi Berkah meliputi inovasi produk, kualitas produk, sosial media terhadap keunggulan bersaing pada batik Jambi khususnya di Batik Berkah Kota Jambi.

\section{Kerangka Teoritis dan Hipotesis}

\section{Inovasi Produk}

Pada umumnya persepsi inovasi diperlihatkan dengan simbol kata yang digunakan. Seleksi nama untuk sebuah inovasi merupakan hal penting dan mempunyai posisi sebagai inovasi dengan ide-ide sebelumnya. Inovasi akan menyatu dengan nilai dan konsisten sehingga kombinasi dari berbagai proses mempengaruhi satu sama lainnya. Keberlanjutan inovasi hadir dengan adanya penciptaan nilai perspektif penciptaan nilai untuk pelanggan, nilai perspektif penciptaan nilai untuk pengusaha, dan perspektif penciptaan nilai gabungan keduanya (Rahab, 2019). Adapun hipotesis yang diajukan sebagai berikut :

$\mathrm{H}_{1}$ : Inovasi Produk berpengaruh terhadap Keunggulan Bersaing di Batik Berkah Kota Jambi.

\section{Kualitas Produk}

Kualitas atau mutu merupakan faktor utama yang harus ada dalam suatu produk sehingga menyebabkan produk tersebut bernilai sesuai dengan tujuan produksi (Ghanita, 2017). Kualitas produk merupakan peranan penting dari sudut konsumen karena pelanggan bebas memilih tingkatan mutu. Kualitas produk juga hal utama yang harus diperhatikan oleh produsen karena dapat memperluas jangkauan pemasaran. Situasi persaingan pemasaran yang semakin ketat membuat peranan kualitas produk akan semakin besar dalam perkembangan perusahaan. Oleh karena itu hipotesis diajukan sebagai berikut : 
$\mathrm{H}_{2}$ : Kualitas Produk berpengaruh terhadap Keunggulan Bersaing di Batik Berkah Kota Jambi.

\section{Sosial Media}

Media sosial merupakan sarana masyarakat dalam berbagi informasi melalui teks, gambar, audio ataupun video satu sama lainnya. Perusahaan juga harus memanfaatkan teknologi ini untuk berbagi informasi produk sehingga dapat terlihat oleh konsumen (Triatmaja, 2016). Media sosial dengan situs jejaring sosial seperti layanan berbasis web memungkinkan individu atau perusahaan menggunakan media sosial sebagai sarana promosi bagi perusahaan. Adapun hipotesis pada variabel ini adalah

$\mathrm{H}_{3}$ : Sosial Media berpengaruh terhadap Keunggulan Bersaing di Batik Berkah Kota Jambi.

\section{Keunggulan Bersaing}

Keunggulan bersaing merupakan hasil dari penerapan strategi yang menggunakan berbagai sumber daya yang dimiliki oleh suatu perusahaan. Unggul bersaing juga merupakan kemampuan perusahaan untuk memperoleh manfaat ekonomi yang lebih tinggi daripada keuntungan yang dapat dicapai oleh pesaing di pasar industri yang sama (Bharadwaj, 2019). Perusahaan yang memiliki keunggulan bersaing selalu memiliki kemampuan untuk memahami perubahan struktur pasar dan dapat memilih strategi pemasaran yang lebih efektif. Strategi ini harus didesain untuk mewujudkan keunggulan bersaing yang terus menerus sehingga perusahaan dapat mendominasi baik di pasar lama maupun pasar baru (Tintin Suhaeni, 2017). Ketiga variabel independen yakni inovasi produk, kualitas produk, sosial media, maka dapat diajukan hipotesis sebagai berikut :

$\mathrm{H}_{4}$ : Inovasi Produk, Kualitas Produk, Sosial Media berpengaruh terhadap Keunggulan Bersaing di Batik Berkah Kota Jambi.

\section{Metode}

Penelitian ini menggunakan pendekatan kuantitatif dari data primer melalui penyebaran kuesioner. Data sekunder juga dilakukan dengan pengamatan langsung kelapangan yaitu melakukan wawancara dengan pemilik galeri Batik Berkah Kota Jambi. Adapun populasi dalam penelitian ini adalah seluruh pelanggan Batik Berkah Kota Jambi. Jumlah sampel yang digunakan dalam penelitian ini sebanyak 100 responden dengan metode penarikan contoh adalah purposive sampling. Metode ini dilakukan karena sampel terpilih harus memenuhi kriteria sampel yaitu konsumen merupakan pelanggan Batik Berkah Kota Jambi dengan minimal pembelanjaan di galeri tersebut sebanyak dua kali. Analisis data ini menggunakan analisis Regresi Linear Berganda. Analisis Regresi merupakan salah satu metode statistika yang dapat digunakan untuk menjelaskan pengaruh variabel penjelas terhadap variabel respon. Adapun variabel penjelas adalah inovasi produk, kualitas produk, sosial media. Variabel respon dalam penelitian ini adalah keunggulan bersaing. Adapun model yang dikembangkan dengan persamaan sebagai berikut: $Y=a+\beta_{1} X_{1}+\beta_{2} X_{2}+$ $\beta_{3} X_{3}+e$

Keterangan: $\mathrm{Y}$ : Keunggulan bersaing; a : konstanta regresi; $\mathrm{X}_{1}$ : Inovasi Produk; $\mathrm{X}_{2}:$ Kualitas Produk; $\mathrm{X}_{3}$ : Sosial Media; $\beta_{1}, \beta_{2}, \beta_{3}$ : Koefisien regresi; e : error

\section{Hasil}

Berdasarkan Tabel 2, persamaan dari model penelitian adalah sebagai berikut : $\mathrm{Y}=0.995+0.258 \mathrm{X} 1+0.200 \mathrm{X} 2+0.294 \mathrm{X} 3+0.458 \mathrm{X} 4+\mathrm{e}$

Berdasarkan hasil Uji-t menyatakan pengaruh per variabel terhadap variabel respon dengan variabel bebas adalah inovasi produk, kualitas produk, dan sosial media. Hasil uji hipotesis menyatakan bahwa hipotesis pertama, kedua, dan ketiga dapat diterima. Hal ini dapat diartikan inovasi produk, kualitas produk, dan sosial media berpengaruh signifikan terhadap keunggulan bersaing di Batik Berkah Kota Jambi.

Tabel 2

Hasil Uji-t dari Analisis Regresi Berganda

\begin{tabular}{|l|r|r|r|l|}
\hline \multicolumn{1}{|c|}{ Model } & Beta & Nilai-t & Nilai-p & \multicolumn{2}{c|}{ Keterangan } \\
\hline Konstanta & 3,545 & 1,439 & 0,153 & - \\
\hline Inovasi produk & 0,270 & 2,747 & 0,007 & $\mathrm{H}_{1}$ diterima \\
\hline Kualitas produk & 0,313 & 2,751 & 0,007 & $\mathrm{H}_{2}$ diterima \\
\hline Sosial media & 0,528 & 4,879 & 0,000 & $\mathrm{H}_{3}$ diterima \\
\hline
\end{tabular}

Sumber : data olahan

Pengaruh bersama-sama variabel inovasi produk, kualitas produk, dan sosial media terhadap keunggulan bersaing ditunjukkan dengan hasil Uji-F (pengujian hipotesis keempat). Hasil uji menyatakan hipotesis diterima dengan inovasi produk, kualitas produk, dan social media secara bersama-sama berpengaruh terhadap keunggulan 
bersaing dengan tingkat signifikansi sebesar 0,000 (lihat Tabel 3). Nilai koefisien determinasi sebesar 0,537 atau $53,7 \%$ dengan arti $53,7 \%$ penelitian ini dipengaruhi oleh variabel inovasi produk, kualitas produk, dan sosial media terhadap keunggulan bersaing di Batik Berkah Kota Jambi. Terdapat 46,3\% dipengaruhi oleh variabel lain di luar dari penelitian ini.

Tabel 3

Hasil Uji- F dari Analisis Regresi Berganda

\begin{tabular}{|l|r|r|r|r|r|c|}
\hline \multicolumn{1}{|c|}{ Model } & Jumlah Kuadrat & \multicolumn{1}{c|}{ Db } & Rata-rata Kuadrat & nilai-F & \multicolumn{1}{c|}{ Nilai-p } & Keterangan \\
\hline Regresi & 283.671 & 3 & 94.557 & 39.281 &, 000 & Hipotesis diterima \\
\hline Eror & 231.089 & 96 & 2.407 & & & \\
\hline Total & 514.760 & 99 & & & & \\
\hline
\end{tabular}

Sumber : data olahan

Berdasarkan hasil Uji-t menunjukkan bahwa variabel inovasi berpengaruh positif secara signifikan terhadap keunggulan bersaing. Penelitian ini sejalan dengan penelitian yang dilakukan oleh Ikhsan Badruz Zaman tahun 2017 tentang pengaruh pengaruh orientasi pasar dan inovasi produk terhadap keunggulan bersaing. Hasil menyatakan bahwa kemampuan perusahaan harus melakukan inovasi terhadap produk dan menjaga produk agar tetap sesuai dengan keinginan dan kebutuhan pelanggan. Dengan demikian, inovasi dapat dijadikan sumber dari keunggulan bersaing perusahaan. Berdasarkan hasil Uji-t dapat dinyatakan bahwa inovasi dapat digunakan untuk meningkatkan keunggulan bersaing (hasil uji-t pada Tabel 2: pengaruh positif). Kualitas produk berpengaruh positif secara signifikan terhadap keunggulan bersaing (hasil Uji-t pada Tabel 2). Kualitas produk dapat ditentukan oleh sekumpulan kegunaan atau fungsinya, seperti daya tahan, ketergantungan pada produk, kenyamanan, dan lain-lain. Kualitas produk perusahaan harus dijaga dengan baik karena semakin baik kualitas produk maka meningkatkan minat pelanggan untuk membeli bahkan membeli secara berulang terhadap produk hal tersebut. Aktivitas ini dapat menjadi strategi perusahaan dalam mempertahankan keunggulan bersaing. Hal ini sejalan dengan penelitian yang dilakukan oleh Rika Devi Kurniasari tahun 2018 yang menyatakan terdapat pengaruh signifikan inovasi produk, kreativitas produk, dan kualitas produk terhadap keunggulan bersaing. Berdasarkan Uji-t menyatakan bahwa variabel sosial media berpengaruh positif secara signifikan terhadap keunggulan bersaing.

Media sosial menjadi wadah atau saluran utama bagi pemilik batik untuk berinteraksi kepada pelanggan. Teknik ini memudahkan pemilik galeri batik untuk memberikan informasi yang lebih cepat dan fleksibel, dan pelanggan akan puas dengan adanya informasi yang diberikan oleh pemilik galeri batik lebih jelas dan lebih cepat. Media sosial juga dapat digunakan sebagai wadah komunikasi untuk mendekatkan kepada konsumen. Hal ini sesuai dengan deskripsi responden yang menyatakan mayoritas konsumen galeri Batik Berkah adalah pengguna media sosial dan berusia muda. Mereka menyatakan merasa puas dengan media sosial galeri batik Berkah dan hal ini jelas akan lebih memudahkan dalam membangun hubungan dengan pelanggan. Hal ini sejalan dengan penelitian yang dilakukan oleh Syarifah Atiqah tentang pengaruh media sosial dan keterampilan wirausaha terhadap keunggulan bersaing pada butik Soscialiteroom Medan. Penelitiaan ini menyatakan bahwa variabel sosial media berpengaruh terhadap keunggulan bersaing. Berdasarkan hasil Uji-F menunjukkan bahwa variabel inovasi produk, kualitas produk, dan sosial media berpengaruh signifikan bersama-sama terhadap keunggulan bersaing di Batik Berkah Kota Jambi. Hal ini sejalan dengan penelitian sebelumnya yang dilakukan oleh Rika Devi Kurniasari yang menyatakan bahwa variabel kreativitas, inovasi, dan kualitas, secara bersama-sama berpengaruh terhadap keunggulan bersaing.

\section{Simpulan}

Inovasi produk, kualitas produk dan sosial media diduga mempunyai pengaruh terhadap keunggulan bersaing. Berdasarkan hasil uji hipotesis, ketiga variabel bebas yaitu inovasi produk, kualitas produk, dan sosial media berpengaruh positif secara signifikan terhadap keunggulan bersaing Batik Berkah Kota Jambi (Hasil Uji-t). Variabel ini secara bersama-sama berpengaruh terhadap keunggulan bersaing di Batik Berkah Kota Jambi (Hasil Uji-F) dengan nilai koefisien determinasi sebesar 53,7\% .Hasil penelitian ini diharapkan menjadi saran dalam pengembangan usaha khususnya bagi pengusaha UMKM dengan cara meningkatkan inovasi produk, kualitas produk, dan sosial media. Faktor ini terus ditingkatkan agar dapat meningkatkan keunggulan bersaing dari pesaing lainnya.

\section{Daftar Pustaka}

Amrullah, Siburian, and Zainurossalamia. (2016). Pengaruh Kualitas Produk dan Kualitas Layanan Terhadap Keputusan Pembelian Sepeda Motor Honda .

Bharadwaj. (2018) .Unit-III:Competency. New Delhi : Indianmba.co

Boedijoewono Nugroho. (2016). Pengantar Statistika Ekonomi dan Bisnis edisi ketujuh. Yogyakarta: Sekolah Tinggi Ilmu Manajemen YKPN. 
Byrd and Turner. (2001). An Exploratory Examination of The Relationship Between Fexible IT Infrastructure and Competitive Advantage Information and Management.

Dismawan. (2013). Pengaruh Kreativitas Produk dan Inovasi Produk Terhadap Keunggulan Bersaing Produk Kue Soes Pada Toko Kue Soes Merdeka Di Jl. Merdeka No. 25 Bandung.

Dita Risha. (2017). Pengaruh Pemilihan Lokasi Usaha dan Pemanfaatan Media Sosial Terhadap Keunggulan Bersaing Pada Batik Sekar Putri Kota Cimahi.

Charles Greer. (2003). Strategic Human Resource Management, Second Edition. New Jersey : Prentice-hall.

Gunelius dan Susan. (2011). 30 Minute Sosial Media Marketing. United States : Mcgraw-Hill Companies.

Gerald Hilss. (2008). Marketing and Entrepreneurship, Researchbldeas and Opportunities. Journal of Small and Medium Entrepreneurship.

Haryono dan Marniyati. (2017). Pengaruh Market Orientation, Inovasi Produk, dan Kualitas Produk Terhadap Kinerja Bisnis Dalam Menciptakan Keunggulan Bersaing.

Husman Husaini dan Purnomo Setiadi, (2017), Metodologi Penelitian Sosial. Jakarta: PT Bumi Aksara.

Ikhsan Badruz Zaman. (2017). Pengaruh Orientasi Pasar dan Inovasi Produk Terhadap Keunggulan Bersaing, Skripsi Fakultas Ekonomi (Yogyakarta : Universitas Negeri Yogyakarta.

Maharani. (2012). Faktor-Faktor Pengaruh Sosial Media Terhadap Keunggulan Bersaing : Studi Kasus Coffee Toffee Indonesia. Jurnal Teknik POMITS.

Mohammad Mozakki. (2020). Pengaruh Diferensiasi Produk Terhadap Keunggulan Bersaing Dimediasi Oleh Inovasi Produk

Netty Laura. (2017). Pengaruh Kualitas produk dan keunggulan bersaing terhadap keputusan pembelian dengan citra merek sebagai variabel intervening. Jakarta : Universitas 17 Agustus 1945.

Nurma Waddah. (2019). Unsur-unsur Estetika Dalam Batik Tulis Jambi, Skripsi Fakultas Ushuluddin. Jambi: Universitas Islam Negeri Sulthan Thaha Saifuddin Jambi.

Rika Devi Kurniasari. (2018). Pengaruh Inovasi Produk, Kreativitas Produk, dan Kualitas Produk Terhadap Keunggulan Bersaing: Studi Kasus pada Produk Kerajinan Enceng Gondok Akar, Skripsi Fakultas Ekonomi. Yogyakarta : Universitas Negeri Yogyakarta.

Philip Kotler dan Kevin Lane Keller. (2009), Manajemen Pemasaran. Jakarta : Erlangga.

Porter E Michael. (1990). The Competitive Advantage of Nations. New York : The Free Press.

Rokhmat Subagiyo. (2017). Metode Penelitian Ekonomi Islam Konsep dan Penerapan. Jakarta : Alim's Publishing.

Sugiyono. (2019). Metode Penelitian Kuantitatif, Kualitatif, dan R\&D. Bandung : Alfabeta.

Syarif Atiqah. (2016). Pengaruh Media Sosial dan Keterampilan Wirausaha Terhadap Keunggulan Bersaing Pada Butik Sosialiteroom Medan. Medan : Universitas Sumatera Utara.

Welly Mulyadi. Dkk. (2016). Pengaruh Inovasi, Kreativitas, Dan Kepuasan Konsumen Terhadap Keunggulan Kompetitif : Studi Kasus Pada Apple, Inc.Tangerang : Universitas Pelita Harapan.

Winda dkk. (2020). Pengaruh Inovasi dan Kualitas Produk Terhadap Keunggulan Bersaing (Studi Pada Payung Geulis Mandiri Tasikmalaya) Jurnal Bisnis Management, 2(1).

Zaki Amir Kelib, (2018). Pengaruh Inovasi Produk Terhadap Keunggulan Bersaing Pada Perusahaan Batik Di Kota Pekalongan Skripsi Fakultas Ekonomi. Yogyakarta : Universitas Islam Indonesia.

Sujarweni. (2015). Metodologi Penelitian Bisnis \& Ekonomi. Yogyakarta: Pustaka Baru Press.

Widiya. (2018). Kreativitas Dan Inovasi Produk Industry Kreatif. Malang : STIE.

Zimmerer dan Scarborough. (2004). Kewirausahaan dan Manajemen dan Manajemen Usaha Kecil. Jakarta : Salemba Empat. 